\title{
Hospital Social Function Reviewed from the Health Law (Verdict Analysis No. 381/Pid.B/2014/PN.TK and Baby Debora Case)
}

Fungsi Sosial Rumah Sakit Ditinjau dari Hukum Kesehatan (Analisis Putusan No. 381/Pid.B/2014/PN.TK dan Kasus Bayi Debora)

\author{
Wahyu Andrianto; Rita Vania Kusumayaningtyas; Rizky Muthiarani \\ email:wahyu.andrianto@ui.ac.id
}

Faculty of Law, University of Indonesia

\begin{abstract}
This paper discuss about the hospital social function. The focus of this research is to discuss about the hospital social function in Indonesia according to the health law. This research is done through a literature study and an analysis on verdict No. 381/Pid.B/2014/PN.TK and Baby Debora Case. This research is a normative juridical research using a qualitative method with a descriptive type. The result of this research conclude that although there is a legislation that regulates the hospital social function, there are still hospitals in Indonesia that has not performed their social function properly. The result of this research suggest that hospitals should maximize the implementation of social functions. The government should organizing the availability of affordable health facilities, periodically socialize the hospital's social functions to hospitals in Indonesia. Furthermore, the government should maximize the implementation of monitoring function and development function.
\end{abstract}

Keywords: Emergency, hospital social function, poor patients

\begin{abstract}
Abstrak: Skripsi ini membahas mengenai fungsi sosial rumah sakit. Fokus dari penelitian ini adalah mengenai fungsi sosial rumah sakit di Indonesia menurut hukum kesehatan. Pembahasan dilakukan melalui studi kepustakaan dan analisis Putusan No. 381/Pid.B/2014/PN.TK serta Kasus Bayi Debora. Penelitian ini adalah penelitian dengan tipe deskriptif, bentuk yuridis normatif dengan metode analisis data kualitatif. Hasil penelitian ini menyimpulkan bahwa meskipun sudah ada peraturan perundang-undangan yang mengatur mengenai fungsi sosial rumah sakit, tetapi masih ada rumah sakit di Indonesia yang belum melaksanakan fungsi sosialnya dengan baik. Hasil dari penelitian ini menyarankan agar sebaiknya rumah sakit memaksimalkan pelaksanaan fungsi sosialnya agar pasien yang kurang/tidak mampu dapat memenuhi kebutuhan akan pelayanan kesehatan. Selain itu untuk pemerintah sebaiknya menyelenggarakan dan memastikan tersedianya fasilitas kesehatan yang terjangkau bagi masyarakat, melakukan sosialisasi berkala berkaitan dengan fungsi sosial rumah sakit kepada rumah sakit-rumah sakit di Indonesia, serta memaksimalkan pelaksanaan fungsi pengawasan dan fungsi pembinaan khususnya berkaitan dengan hak dan kewajiban dari pasien dan rumah sakit.
\end{abstract}

Kata Kunci: Fungsi sosial rumah sakit, gawat darurat, pasien tidak mampu

\section{PENDAHULUAN}

Rumah sakit merupakan institusi pelayanan kesehatan yang menyelenggarakan pelayanan kesehatan perorangan secara paripurna, baik promotif, kuratif, maupun rehabilitatif, yang menyediakan pelayanan rawat inap, rawat jalan, dan gawat darurat. ${ }^{1}$ Dahulu sampai sekitar tahun 1960, rumah sakit di Indonesia bersifat murni untuk amal karena uang yang diperoleh rumah sakit berasal dari sumbangan- sumbangan yang tujuannya khusus untuk menolong orang sakit tanpa menerima imbalan apapun. Sekitar tahun 1965, rumah sakit mulai sulit

\footnotetext{
1 Indonesia, Undang-Undang Rumah Sakit, UU No. 44 Tahun 2009, LN No. 153 Tahun 2009, TLN No. 5072, Ps. 1 ayat (1).
} 
SOEPRA Jurnal Hukum Kesehatan

TERAKREDITASI RISTEKDIKTI Peringkat 4

ISSN:2548-818X (media online) Vol. 7 (1) Juni 2021

untuk memperoleh sumbangan dari para dermawan dan mengakibatkan kesulitan untuk menutupi pengeluaran rumah sakit. ${ }^{2}$

Seiring perkembangan zaman tersebut, rumah sakit tidak lagi hanya bisa dipandang sebagai institusi sosial belaka, tetapi sudah berkembang menjadi institusi yang bersifat sosio ekonomis. Mulailah bermunculan rumah sakit milik swasta yang berorientasi mencari keuntungan karena adanya kemajuan teknologi kedokteran dan meningkatnya ekonomi masyarakat Indonesia yang ditandai dengan munculnya golongan menengah ke atas. Hingga pada tahun 1990 diterbitkan Peraturan Menteri Kesehatan No. 84 Tahun 1990 tentang Perubahan Atas Peraturan Menteri Kesehatan Republik Indonesia Nomor 920/MENKES/PER/XXI/1986 tentang Upaya Pelayanan Kesehatan Swasta di Bidang Medik yang bagian dari isinya membuka peluang untuk mendirikan rumah sakit oleh sebuah Perseroan Terbatas (PT). ${ }^{3}$

Undang-Undang No. 44 Tahun 2009 tentang Rumah Sakit ("UU Rumah Sakit") membedakan rumah sakit berdasarkan pengelolaannya yaitu rumah sakit publik dan rumah sakit privat. Rumah sakit publik dapat dikelola oleh pemerintah, pemerintah daerah dan badan hukum yang bersifat nirlaba (non-profit). Sedangkan rumah sakit privat dikelola oleh badan hukum dengan tujuan profit (for profit) yang berbentuk Perseroan Terbatas atau Persero yang antara lain dikelola oleh BUMN dan swasta (perorangan, perusahaan dan swasta lainnya). ${ }^{4}$ Rumah Sakit diselenggarakan berasaskan Pancasila dan didasarkan kepada nilai kemanusiaan, etika dan profesionalitas, manfaat, keadilan, persamaan hak dan anti diskriminasi, pemerataan, perlindungan dan keselamatan pasien, serta mempunyai fungsi sosial. Yang dimaksud "fungsi sosial rumah sakit" adalah bagian dari tanggung jawab yang melekat pada setiap rumah sakit, yang merupakan ikatan moral dan etik dari rumah sakit dalam membantu pasien khususnya yang kurang/tidak mampu untuk memenuhi kebutuhan akan pelayanan kesehatan. ${ }^{5}$

Dalam Pasal 29 ayat (1) huruf f UU Rumah Sakit dijelaskan bahwa salah satu kewajiban rumah sakit ialah untuk melaksanakan fungsi sosial, antara lain dengan memberikan fasilitas pelayanan pasien tidak mampu/miskin, pelayanan gawat darurat tanpa uang muka, ambulan gratis, pelayanan korban bencana dan kejadian luar biasa, atau bakti sosial bagi misi kemanusiaan. Pasal 3 Kode Etik Rumah Sakit (“KODERSI") mengatur bahwa rumah sakit berkewajiban menyelenggarakan pelayanan pengobatan dan pemulihan kesehatan yang aman, mengutamakan kepentingan pasien dan keluarga, bermutu, non diskriminasi, efektif, dan efisien sesuai dengan standar pelayanan rumah sakit. Selain itu, di dalam Pasal 9 diatur bahwa rumah sakit juga harus mengutamakan pelayanan yang baik dan bermutu secara berkesinambungan serta tidak mendahulukan urusan biaya, rumah sakit harus melaksanakan fungsi sosial dengan menyediakan fasilitas pelayanan kepada pasien tidak mampu/miskin, pasien gawat darurat, dan korban bencana. Dengan demikian, diketahui bahwa disamping mencari keuntungan, rumah sakit juga harus menjalankan fungsi sosialnya sesuai yang diamanatkan oleh peraturan perundang-undangan. Namun, kerap kali ditemui persoalan yang mana rumah sakit tidak menjalankan fungsi sosialnya dengan baik.

\footnotetext{
2 J. Guwandi, Hospital Law Emerging Doctrines and Jurisprudence (Jakarta: Balai Penerbit Fakultas Kedokteran Universitas Indonesia, 2002), hlm. 2-3.

3 Ibid.

${ }^{4}$ Indonesia, Undang-Undang Rumah Sakit, Ps. 20 dan Ps. 21.

5 Ibid., Ps. 2 dan penjelasannya.
} 
SOEPRA Jurnal Hukum Kesehatan

TERAKREDITASI RISTEKDIKTI Peringkat 4

ISSN:2548-818X (media online) Vol. 7 (1) Juni 2021

Bukti nyata suatu rumah sakit tidak menjalankan fungsi sosialnya dapat dilihat dari kasus Kakek Suparman, Pasien Rumah Sakit Umum Daerah Dr. A Dadi Tjokrodipo Bandar Lampung ("RSUD Dr. A Dadi Tjokrodipo Bandar Lampung"), yang dibuang oleh 6 pekerja rumah sakit tersebut di sebuah gubuk yang mengakibatkan kematiannya. Pasien Suparman dibawa ke RSUD Dr. A Dadi Tjokrodipo Bandar Lampung pada hari Jumat, tanggal 17 Januari 2014, ia didiagnosa mengalami Dehidrasi Low Intake atau kekurangan asupan makanan dan minuman serta mengalami infeksi bakteriil. Selama berada dalam perawatan, Pasien Suparman sering mengamuk, berteriak, gelisah dan sulit diajak berkomunikasi. Pada akhirnya, seorang pegawai rumah sakit tersebut diperintahkan oleh atasannya untuk membuang Pasien Suparman. Pegawai tersebut kemudian meminta bantuan lima orang pegawai lainnya untuk bersama-sama membuang Pasien Suparman ke sebuah gubuk di pinggir Jalan Raden Imba Kesuma, Bandar Lampung. Pada hari Selasa, tanggal 21 Januari 2014, Pasien Suparman ditemukan warga dalam kondisi lemah dan tidak bisa bicara. Lalu, ia dibawa kembali ke RSUD Dr. A Dadi Tjokrodipo Bandar Lampung, namun dirujuk ke Rumah Sakit Umum Daerah Abdul Moeloek ("RSUD Abdul Moeloek") sebelum akhirnya meninggal enam jam kemudian. Kasus ini diproses di pengadilan dengan nomor register perkara 381/Pid.B/2014/PN.TK, yang mana Para Terdakwa masing-masing dihukum 14 bulan penjara karena terbukti secara sah bersalah dan melanggar ketentuan Pasal 306 ayat (2) Kitab Undang-Undang Hukum Pidana (“KUHP”) jo. Pasal 55 ayat (1) ke-1 KUHP. ${ }^{6}$

Selain itu, terdapat juga kasus yang mendapat sorotan dari masyarakat luas yang berhubungan dengan pelaksanaan fungsi sosial rumah sakit, yakni kasus bayi Debora. Tiara Debora Simanjorang, bayi mungil berusia 4 bulan meninggal di Instalasi Gawat Darurat Rumah Sakit Mitra Keluarga Kalideres ("RS Mitra Keluarga Kalideres"). Nyawa Debora tak tertolong lantaran telat mendapat perawatan karena terkendala masalah uang muka. Pada hari Minggu, tanggal 3 September 2017, Debora batuk-batuk berdahak dan kemudian diikuti sesak nafas. Kedua orangtuanya segera membawa bayinya ke Rumah Sakit Mitra Keluarga Kalideres. Disana, Bayi Debora dilarikan ke Instalasi Gawat Darurat (“IGD”). Dokter jaga yang sedang bertugas waktu itu, Dokter Iren langsung mengambil tindakan pertolongan pertama. Hasil diagnosa dokter Iren mengatakan bayi Debora harus segera dibawa ke ruang Pediatric Intensive Care Unit ("PICU") karena kondisinya memburuk untuk memberikan pertolongan maksimal. Orang tua Debora diminta untuk membayar uang muka Rp 19.800.000 agar anak mereka bisa segera masuk ruang PICU. Namun, pada saat itu keduanya tidak punya cukup uang. Ayah Debora mengatakan bahwa ia memiliki BPJS dan memohon agar bayinya diselamatkan lebih dulu. Namun, ternyata pihak rumah sakit mengaku belum bekerjasama dengan BPJS dan meminta untuk tetap melunasi uang muka. Kondisi Debora terus menurun, kedua orang tuanya berencana dipindah ke Rumah Sakit Koja ("RS Koja”). Pukul 10.00 WIB, perawat memanggil kedua orang tua Debora, mereka mengabarkan kondisi bayi Debora semakin memburuk. Mereka memberikan tindakan CPR karena jantung bayi Debora berhenti. Namun, nyawa Debora sudah tidak bisa diselamatkan. ${ }^{7}$

Terhadap kasus bayi Debora tersebut, Dinas Kesehatan DKI Jakarta membentuk tim investigasi untuk melakukan audit medis dan manajemen di RS Mitra Keluarga Kalideres. Dari hasil audit medis, disebutkan bahwa Dokter IGD yang menangani bayi Debora sudah

\footnotetext{
${ }^{6}$ Fariz Fardianto, “6 Terdakwa Pembuang Pasien di Bandar Lampung di Vonis 14 Bulan," https://www.merdeka.com/peristiwa/6-terdakwa-pembuang-pasien-di-bandar-lampung-divonis-14bulan.html, diakses 3 November 2017.

7 “Bayi Debora Meninggal di IGD RS Mitra Keluarga, Uang Muka Jadi Kendala," https://kumparan.com/salmahmuslimah/bayi-debora-meninggal-di-igd-rs-mitra-keluarga-uang-muka-jadi-kendala, diakses 3 November 2017.
} 
melakukan penanganan medis dengan baik. Namun, terhadap hasil audit manajemen, tim investigasi menyimpulkan bahwa Direktur RS Mitra Keluarga Kalideres kurang memahami peraturan perundang-undangan terkait rumah sakit, yang mana mengatur bahwa pasien gawat darurat tidak boleh dimintai uang muka dan tidak boleh dirujuk sebelum kondisinya stabil. Sebagaimana telah diuraikan di atas, timbul pertanyaan terkait bagaimana pengaturan mengenai fungsi sosial rumah sakit di Indonesia? Mengapa masih banyak pasien tidak mampu yang ditelantarkan? Mengapa pasien dalam keadaan kritis masih harus dimintai uang muka? Berbagai permasalahan tersebut membutuhkan kajian lebih dalam karena sampai saat ini walaupun peraturan perundang-undangan sudah ada yang mengatur mengenai hal tersebut, namun masih ada rumah sakit yang tidak patuh akan peraturan tersebut dan menyebabkan pasien meninggal dunia.

\section{RUMUSAN MASALAH}

Berdasarkan permasalahan yang telah diuraikan dalam latar belakang di atas, maka pokok permasalahan yang akan dibahas ialah sebagai berikut:

1. Bagaimanakah pengaturan fungsi sosial rumah sakit di Indonesia ditinjau dari hukum kesehatan?

2. Bagaimana analisis penerapan fungsi sosial rumah sakit dalam Putusan No. 381/Pid.B/2014/PN.TK dan kasus bayi Debora?

\section{METODE PENELITIAN}

\section{Bentuk Penelitian}

Dalam penelitian hukum ini, penulis menggunakan bentuk penelitian yuridis normatif, yaitu metode penelitian hukum yang dilakukan dengan meneliti bahan pustaka atau data sekunder belaka. ${ }^{8}$ Dengan menggunakan metode ini, diharapkan dapat menjawab permasalahan- permasalahan yang terdapat dalam penelitian ini, yaitu mengenai fungsi sosial rumah sakit di Indonesia, sesuai dengan asas-asas hukum yang ada, hukum positif terkait permasalahan, dan beberapa teori pendukung lainnya.

\section{Tipe Penelitian}

Tipe Penelitian yang digunakan dalam penelitian ini adalah penelitian deskriptif. Penelitian deskriptif adalah penelitian yang bertujuan menggambarkan sifat suatu individu, keadaan, gejala, atau kelompok tertentu, atau menentukan frekuensi suatu gejala. ${ }^{9}$ Penelitian ini mencoba untuk memberikan penggambaran dan penjelasan lebih mendalam mengenai fungsi sosial rumah sakit di Indonesia yang bertujuan untuk memberikan fasilitas pelayanan kesehatan kepada pasien tidak mampu.

\section{Jenis Data}

Jenis data yang digunakan dalam penelitian ini adalah data sekunder, yang terdiri dari:

a. Bahan Hukum Primer, yaitu bahan hukum yang mempunyai kekuatan mengikat, yang berupa peraturan perundang-undangan Indonesia yang berhubungan dengan penelitian dan penulisan skripsi ini ${ }^{10}$ di antaranya adalah Undang-Undang No. 36 Tahun

\footnotetext{
8 Soerjono Soekanto \& Sri Mamudji, Penelitian Hukum Normatif (Suatu Tinjauan Singkat) (Jakarta: Rajawali Pers, 2001), hlm. 12.

9 Sri Mamudji, et. al., Metode Penelitian dan Penulisan Hukum (Jakarta: Badan Penerbit Fakultas Hukum Universitas Indonesia, 2005), hlm. 10.

${ }^{10}$ Soekanto \& Mamudji, Penelitian Hukum Normatif, hlm. 18.
} 
2009 tentang Kesehatan, Undang-Undang No. 36 Tahun 2014 tentang Tenaga Kesehatan, Undang-Undang No. 29 Tahun 2004 tentang Praktik Kedokteran, UndangUndang No. 44 Tahun 2009 tentang Rumah Sakit.

b. Bahan Hukum Sekunder, yaitu bahan hukum yang memberikan informasi yang erat kaitannya dengan bahan hukum primer dan implementasinya, serta dapat membantu menganalisa, memahami dan menjelaskan bahan hukum primer. ${ }^{11}$ Bahan hukum sekunder yang dipergunakan dalam penulisan ini diantaranya terdiri dari Buku Etika dan Hukum Kesehatan karya Soekidjo Notoatmodjo, Buku Pengantar Hukum Kesehatan Indonersia karya CST Kansil, Buku Dokter dan Rumah Sakit karya J. Guwandi, Buku Hukum Rumah Sakit \& Corporate Liability karya J. Guwandi.

c. Bahan Hukum Tersier, yaitu bahan hukum yang memberikan petunjuk maupun penjelasan atas bahan hukum primer dan bahan hukum sekunder. Bahan hukum tersier yang digunakan dalam penelitian ini adalah kamus hukum dalam Bahasa Inggris, yaitu Black's Law Dictionary oleh Bryan A. Garner.

\section{Metode Pengumpulan Data}

Dalam melaksanakan penelitian umumnya dikenal tiga jenis alat pengumpulan data, yaitu studi dokumen, pengamatan dan wawancara. Ketiganya dapat dipergunakan masingmasing, atau bersama-sama. ${ }^{12}$ Penulis melakukan wawancara untuk memperoleh keterangan dari beberapa pihak, yaitu Bapak M. Luthfie Hakim, S.H., M.H., selaku Pengacara Rumah Sakit Mitra Keluarga Kalideres dan Bapak Dr. dr. Supriyantoro, Sp.P., MARS, selaku Ketua Badan Pengawas Rumah Sakit Provinsi DKI Jakarta.

\section{Metode Analisis Data}

Metode analisis data yang penulis pergunakan adalah metode kualitatif, yaitu mendalami makna dibalik realitas atau tindakan atau data yang diperoleh dan yang diteliti atau dipelajari adalah obyek penelitian yang utuh. ${ }^{13}$ Dalam penelitian ini, pengolahan keseluruhan data yang telah penulis peroleh dilakukan secara sistematis dan kualitatif agar menghasilkan tulisan yang deskriptif analitis mengenai fungsi sosial rumah sakit ditinjau dari hukum kesehatan.

\section{PEMBAHASAN}

\section{Pengaturan Fungsi Sosial Rumah Sakit di Indonesia Ditinjau dari Hukum Kesehatan}

Hukum kesehatan meliputi semua ketentuan hukum yang langsung maupun tidak langsung berhubungan dengan pemeliharaan kesehatan dan penerapan dari hukum perdata, hukum pidana dan hukum administratif dalam hubungan tersebut. Hukum kesehatan mencakup komponen hukum bidang kesehatan yang menyangkut hukum kedokteran, hukum keperawatan, hukum farmasi klinik, dan hukum rumah sakit. Pada kaitannya dengan bidang pelayanan kesehatan (health care), terdapat dua kelompok subjek hukum kesehatan, diantaranya adalah:

1) Manusia sebagai subjek hukum kesehatan, yang terdiri atas:

\footnotetext{
${ }^{11}$ Mamudji, et. al., Metode Penelitian dan Penulisan Hukum, hlm. 31.

${ }^{12}$ Soerjono Soekanto, Pengantar Penelitian Hukum (Depok: UI Press, 2007), hlm. 21.

${ }^{13}$ Mamudji, et. al., Metode Penelitian dan Penulisan Hukum, hlm. 67.
} 
a. Health receivers, yaitu penerima pelayanan kesehatan, dimana yang termasuk dalam kelompok ini adalah orang yang sakit (pasien) dan mereka yang ingin memelihara atau meningkatkan kesehatannya (non pasien);

b. Health providers, yaitu pemberi pelayanan kesehatan. Contohnya adalah dokter, dokter gigi, ataupun tenaga bidang kesehatan lainnya seperti apoteker, asisten apoteker, bidan, perawat, analis/laboran, ahli gizi, dan lain-lain.

2) Badan hukum sebagai subjek hukum kesehatan, sebagai contohnya adalah yayasan, Perseroan Terbatas, maupun pemerintah yang memiliki rumah sakit.

Salah satu subyek hukum kesehatan, yakni rumah sakit, memegang peranan yang sangat penting dalam menunjang baik pelayanan kesehatan maupun pelayanan medis. Pelayanan kesehatan pada rumah sakit merupakan hal yang penting dan harus dijaga maupun ditingkatkan kualitasnya sesuai standar pelayanan yang berlaku agar masyarakat sebagai konsumen yang dapat merasakan pelayanan kesehatan yang diberikan. Terdapat tiga komponen yang terlibat dalam suatu proses pelayanan yaitu: pelayanan sangat ditentukan oleh kualitas pelayanan yang diberikan, siapa yang melakukan pelayanan, serta konsumen yang menilai sesuatu pelayanan melalui harapan yang diinginkan. Dalam rangka penyelenggaraan pelayanan kesehatan secara berjenjang dan fungsi rujukan, rumah sakit umum dan rumah sakit khusus diklasifikasikan berdasarkan fasilitas dan kemampuan pelayanan Rumah Sakit. ${ }^{14}$

Menurut UU Rumah Sakit, rumah sakit mempunyai tugas memberikan pelayanan kesehatan perorangan secara paripurna. Pelayanan kesehatan paripurna adalah pelayanan kesehatan yang meliputi promotif, preventif, kuratif, dan rehabilitatif. Dalam menjalankan tugas tersebut, rumah sakit memiliki hak dan kewajiban. Berdasarkan Pasal 30 UU Rumah Sakit, diketahui bahwa hak yang dimiliki rumah sakit diantaranya adalah menerima imbalan jasa pelayanan, melakukan kerja sama dengan pihak lain dalam rangka mengembangkan pelayanan, menggugat pihak yang mengakibatkan kerugian, mendapatkan perlindungan hukum dalam melaksanakan pelayanan kesehatan, dan lain-lain. ${ }^{15}$

Sementara itu, Pasal 29 ayat (1) UU Rumah Sakit menyebutkan beberapa kewajiban dari rumah sakit, antara lain memberikan pelayanan kesehatan yang aman, bermutu, antidiskriminasi dan efektif dengan mengutamakan pasien sesuai standar pelayanan rumah sakit, memberikan pelayanan gawat darurat kepada pasien sesuai dengan kemampuan pelayanannya, melaksanakan fungsi sosial antara lain dengan memberikan fasilitas pelayanan pasien tidak mampu/miskin, pelayanan gawat darurat tanpa uang muka, ambulan gratis, pelayanan korban bencana dan kejadian luar biasa, atau bakti sosial bagi misi kemanusiaan, dan lain-lain. ${ }^{16}$ Atas setiap pelanggaran dari kewajiban tersebut, akan dikenakan sanksi administratif yang berupa teguran, teguran tertulis atau denda dan pencabutan izin rumah sakit. ${ }^{17}$

Dalam peranannya sebagai organisasi penyelenggaraan pelayanan publik, rumah sakit bertanggung jawab atas setiap pelayanan jasa publik kesehatan yang diselenggarakannya. Tanggung jawab tersebut yaitu, menyelenggarakan pelayanan

\footnotetext{
${ }^{14}$ Indonesia, Undang-Undang Rumah Sakit, Ps. 24 ayat (1).

15 Ibid., Ps. 30.

${ }^{16}$ Ibid., Ps. 29 ayat (1).

17 Ibid., Ps. 29 ayat (2).
} 
kesehatan yang bermutu terjangkau berdasarkan prinsip aman, menyeluruh, non diskriminatif, partisipatif dan memberikan perlindungan bagi masyarakat sebagai pengguna jasa pelayanan kesehatan (health receiver), juga bagi penyelenggara pelayanan kesehatan demi untuk mewujudkan derajat kesehatan yang setinggitingginya. ${ }^{18}$ Mengenai tanggung gugat rumah sakit atau tanggung jawab atas segala perbuatan yang dilakukan oleh tenaga kesehatannya juga diatur dalam peraturan perundang-undangan Indonesia. Hal ini diatur di dalam Pasal 46 UU Rumah Sakit yang mengatur bahwa rumah sakit bertanggung jawab atas semua kerugian yang timbul akibat dari perbuatan tenaga kesehatan di rumah sakit. ${ }^{19}$ Artinya, pasien dapat menuntut dan menggugat rumah sakit atas kerugian yang ia terima atas tindakan dari tenaga kesehatan di rumah sakit tersebut tanpa perlu memikirkan tentang relasi hukum dan tanggung jawab profesi tenaga kesehatan yang berbeda-beda karena menurut Pasal 46 ini, rumah sakitlah yang akan bertanggung jawab atas semua kerugian yang timbul.

Salah satu bentuk tanggung jawab yang melekat pada setiap rumah sakit ialah fungsi sosial, yang merupakan ikatan moral dan etik dari rumah sakit dalam membantu pasien khususnya yang kurang/tidak mampu untuk memenuhi kebutuhannya akan pelayanan kesehatan. Fungsi sosial ini tidak mengambil keuntungan secara komersial tetapi lebih menitikberatkan pada kemanusiaan. ${ }^{20}$ Rumah sakit yang semula memiliki fungsi sosial yang dominan kini telah berubah menjadi industri jasa yang memiliki kemampuan untuk memperoleh keuntungan. Sesuai perannya, rumah sakit merupakan industri yang padat modal, padat karya, padat ilmu dan teknologi. Namun, dalam menyelenggarakan kegiatannya, rumah sakit tidak boleh mengutamakan keuntungannya karena rumah sakit yang kegiatannya memberikan pelayanan kesehatan tetap harus memperhatikan fungsi sosialnya.

Bentuk-bentuk fungsi sosial rumah sakit yang wajib dilaksanakan diatur dalam Pasal 2 ayat (1) Peraturan Menteri Kesehatan RI No. 378/Menkes/V/1993, tentang Pelaksanaan Fungsi Sosial Rumah Sakit Swasta, yang dua diantaranya ialah pembebasan biaya pelayanan bagi masyarakat yang tidak mampu dan pelayanan gawat darurat dalam 24 jam tanpa mempersyarakatkan uang muka, tetapi mengutamakan pelayanan. ${ }^{21}$ Selanjutnya, Pasal 2 ayat (2) dijelaskan bahwa terhadap rumah sakit swasta dapat mengembangkan fungsi sosialnya, dengan cara mengembangkan pelayanan dasar di luar rumah sakit bagi masyarakat yang kurang/tidak mampu, menyelenggarakan pendidikan dan/atau penelitian tenaga rumah sakit, dan pelayanan kesehatan lain yang diutamakan untuk meningkatkan derajat kesehatan masyarakat. ${ }^{22}$ Bagi rumah sakit swasta yang tidak melaksanakan fungsi sosial sebagaimana diatur dalam Pasal 2 tersebut, dapat dikenakan sanksi administratif berupa terguran sampai dengan peninjauan kembali izin penyelenggaraan rumah sakit. ${ }^{23}$

\footnotetext{
18 H. Syahrul Machmud, Penegakan Hukum dan Perlindungan Bagi Dokter yang Diduga Melakukan Medikal Malpraktek (Bandung: CV. Karya Putra Darwati, 2012), hlm. 161.

19 Indonesia, Undang-Undang Rumah Sakit, Ps. 46.

${ }^{20}$ CST Kansil, Pengantar Hukum Kesehatan Indonesia (Jakarta: PT Rineka Cipta, 1991), hlm. 2.

${ }^{21}$ Indonesia, Menteri Kesehatan, Peraturan Menteri Kesehatan tentang Pelaksanaan Fungsi Sosial Rumah Sakit Swasta, No. PM 378 Tahun 1993, Ps. 2 ayat (1).

${ }^{22}$ Ibid., Ps. 2 ayat (2).

23 Ibid., Ps. 9.
} 
Selain itu, dalam Keputusan Menteri Kesehatan No. 129/Menkes/SK/II/2008 tentang Standar Pelayanan Minimal Rumah Sakit mengatur mengenai jenis pelayanan, indikator, dan standar untuk gawat darurat, yang di antaranya ialah ketentuan tidak adanya pasien yang diharuskan membayar uang muka. Tujuannya adalah terselenggaranya pelayanan yang mudah diakses dan mampu dengan segera memberikan pertolongan pada pasien gawat darurat. Pasal 9 KODERSI juga mengatur bahwa rumah sakit harus mengutamakan pelayanan yang baik dan bermutu secara berkesinambungan serta tidak mendahulukan urusan biaya. Apabila pimpinan fasilitas pelayanan kesehatan dan/atau tenaga kesehatan yang melakukan praktik atau pekerjaan pada fasilitas pelayanan kesehatan dengan sengaja tidak memberikan pertolongan pertama terhadap pasien yang dalam keadaan darurat, maka dipidana dengan pidana penjara paling lama 2 (dua) tahun dan denda paling banyak Rp200.000.000,00 (dua ratus juta rupiah). Dalam hal perbuatan tersebut dapat mengakibatkan terjadinya kecacatan atau kematian, dipidana dengan pidana penjara paling lama 10 (sepuluh) tahun dan denda paling banyak Rp1.000.000.000,00 (satu miliar rupiah). ${ }^{24}$

Sebagai salah satu bentuk pelaksanaan fungsi sosial, rumah sakit harus dapat memberikan fasilitas pelayanan pasien tidak mampu/miskin. Apabila dikaitkan dengan biaya, sebelum era JKN, biasanya pasien yang kurang mampu, akan diberikan Surat Keterangan Tidak Mampu (SKTM). Terhadap SKTM tersebut, warga tidak mampu bisa mendapatkan perawatan dan pengobatan gratis ataupun diberikan pengurangan biaya di rumah sakit yang melayani SKTM. Dasarnya adalah Peraturan Menteri Kesehatan tentang Standar Tarif Rumah Sakit. Peraturan tersebut telah beberapa kali terbit menyesuaikan dengan perkembangan yang ada. Peraturan Menteri Kesehatan RI No. 85 Tahun 2015 tentang Pola Tarif Nasional Rumah Sakit, yang merupakan peraturan terbaru, dalam Pasal 23 ayat (1) mengatur bahwa Kepala atau Direktur Rumah Sakit dapat membebaskan sebagian atau seluruh tarif sampai dengan 0\% (nol perseratus) dari tarif kegiatan pelayanan untuk pasien tidak mampu membayar dan kondisi atau situasi tertentu dengan memperhatikan kemampuan keuangan rumah sakit. ${ }^{25}$ Dalam pasal tersebut terdapat klausul "dengan memperhatikan kemampuan keuangan rumah sakit". Hal ini berarti bahwa walaupun sudah diberi ruang untuk memberikan keringanan dengan syarat-syarat tertentu, ada hal yang harus diperhatikan, yaitu kemampuan keuangan rumah sakit. Hal tersebut dikarenakan, rumah sakit tetap berkewajiban untuk menjaga keberlangsungan operasionalnya.

Selain itu, rumah sakit juga harus harus menyediakan pelayanan gawat darurat selama 24 jam dalam sehari dan tujuh hari dalam seminggu. Pelayanan gawat darurat diberikan tanpa membedakan kemampuan (sosio-ekonomi) pasien namun mengutamakan "life saving". Dalam memberikan pelayanan, tidak ada pasien yang diharuskan membayar uang muka terlebih dahulu, baik pada waktu pemeriksaan fisik, pemeriksaan penunjang medik maupun pada waktu melakukan tindakan medik. ${ }^{26} \mathrm{Hal}$ ini bertujuan untuk terselenggaranya pelayanan yang mudah diakses dan mampu segera

\footnotetext{
${ }^{24}$ Indonesia, Undang-Undang Kesehatan, UU No. 36 Tahun 2009, LN No. 144 Tahun 2009, TLN No. 5063, Ps. 190 ayat (1) dan (2).

25 Indonesia, Menteri Kesehatan, Peraturan Menteri Kesehatan tentang Pola Tarif Nasional Rumah Sakit, No. PM 85 Tahun 2015, Ps. 23 ayat (1).

${ }^{26}$ Wahyu Andrianto, "Penanaman Modal Asing pada Rumah Sakit, Implikasi pada Fungsi Sosial dan Orientasi Profit," (Skripsi Universitas Indonesia, Depok, 2002), hlm. 96-97.
} 
memberikan pertolongan pada pasien gawat darurat. Rujukan penderita gawat darurat ke rumah sakit lain/rumah sakit pemerintah diperbolehkan asalkan berdasarkan pertimbangan medis teknis dan keterbatasan fasilitas pada rumah sakit tersebut, bukan berdasarkan kemampuan (sosio-ekonomi) pasien. Pertolongan pertama sebelum rujukan harus diberikan secara adekuat. ${ }^{27}$ Pertama kali kebijakan tentang pelayanan gawat darurat tanpa memungut uang muka diatur dalam Pasal 24 ayat (2), Peraturan Menteri Kesehatan RI No. 920/Menkes/Per/XII/1986 tentang Pelayanan Kesehatan Swasta di Bidang Medik. Hal tersebut yaitu upaya pelayanan kesehatan swasta di bidang medik harus memberikan pertolongan pertama kepada penderita gawat darurat tanpa memungut uang muka terlebih dahulu. ${ }^{28}$

Rumah sakit di Indonesia mayoritas sudah menjalankan fungsi sosialnya dengan baik. Namun, masih ada rumah sakit-rumah sakit yang belum menjalankan fungsi sosialnya dengan baik seperti menolak pasien, membedakan pelayanan bagi pasien tidak mampu dengan pasien yang mampu, membedakan pelayan pasien kelas tiga dengan pasien kelas satu misalnya ataupun pasien BPJS dengan pasien non-BPJS dan sebagainya. Padahal, rumah sakit mempunyai kewajiban untuk menjalankan fungsi sosialnya. Salah satu hal yang dikeluhkan rumah sakit, utamanya rumah sakit swasta, yaitu regulasi-regulasi yang ada di Indonesia ketika berbicara mengenai kewajiban, rumah sakit tidak boleh menolak pasien, rumah sakit harus mengedepankan fungsi sosial, dan lain sebagainya. Ketika berbicara tentang kewajiban pajak, diberlakukan pajak-pajak yang tidak berbeda dengan bisnis lainnya. Ketika rumah sakit investasi, tidak ada subsidi harga alat kesehatan. Harga-harga alat kesehatan mahal karena biaya masuk (impor) alat kesehatan di Indonesia tidak dibebaskan, masih ada beban- beban yang harus dibayarkan. ${ }^{29}$

2. Analisis Penerapan Fungsi Sosial Rumah Sakit dalam Putusan No. 381/Pid.B/2014/PN.TK dan Kasus Bayi Debora

Dalam penelitian ini, penulis akan menguraikan duduk perkara dari kasus pasien Suparman, pasien dari RSUD Dr. A Dadi Tjokrodipo Bandar Lampung dalam putusan No. 381/Pid.B/2014/PN.TK serta kasus bayi Debora, pasien RS Mitra Keluarga Kalideres . Kemudian, penulis akan menganalisis penerapan fungsi sosial rumah sakit terhadap kedua kasus tersebut.

1) Putusan No. 381/Pid.B/2014/PN.TK (Kasus Pasien Suparman)

Pada hari Jumat tanggal 17 Januari 2014 sekitar pukul 14.00 WIB, RSUD Dr. A Dadi Tjokrodipo Bandar Lampung menerima pasien yang terakhir diketahui bernama Suparman bin Sariun alias Mbah Edi alias Darnoh. Pasien dirawat di IGD rumah sakit tersebut dan didiagnosa mengalami Dehidrasi Low Intake (dehidrasi karena kekurangan asupan makanan dan minuman) ditambah dengan Suspect Bakterian Infection (kecurigaan infeksi bakteri). Berdasarkan hasil diagnosa dokter IGD tersebut, pasien dipindahkan ke ruangan rawat inap E2. Pada hari Sabtu, 18 Januari 2014, pasien kembali diperiksa oleh dokter jaga yang bertugas pada saat itu yaitu dr. Melisha Lisman Gaya. Dari hasil pemeriksaan, dicurigai pasien mengalami gangguan kejiwaan karena

\footnotetext{
${ }^{27}$ Ibid., hlm. 97.

${ }^{28}$ Indonesia, Menteri Kesehatan, Peraturan Menteri Kesehatan tentang Pelayanan Kesehatan Swasta di Bidang Medik, No. PM 920 Tahun 1986, Ps. 24 ayat (2).

29 Wawancara dengan Dr. dr. Supriyantoro, Sp.P., MARS, Ketua Badan Pengawas Rumah Sakit Provinsi DKI Jakarta, 19 Desember 2017.
} 
selama dalam perawatan di ruangan rawat inap E2 pasien suka berteriak-teriak, tidak bisa berkomunikasi dengan baik dan kondisinya masih lemah. Karena pasien tersebut gaduh, atas permintaan keluarga pasien lain yang dirawat di ruangan E2 akhirnya pasien tersebut dipindahkan ke selasar ruangan rawat inap E2. Pada hari Senin, 20 Januari 2014 Mahendri selaku kepala ruangan E2 melapor kepada Heriyansyah, Kasubag Umum Kepegawaian dan Humas yang menyetujui masuknya pasien tersebut untuk menanyakan tindak lanjut atas pasien tersebut. Kemudian, Heriyansyah memerintahkan Mahendri untuk membuangnya.

Sekitar pukul 14.00 WIB Mahendri memerintahkan Terdakwa III, Terdakwa IV dan Terdakwa $V$ untuk tidak pulang terlebih dahulu untuk membantunya membuang pasien yang berada di ruangan rawat inap E2 yang tidak ada keluarganya tersebut. Mahendri menghubungi Terdakwa I untuk membawa mobil ambulance ke ruang rawat inap belakang untuk membawa orang gila. Kemudian Mahendri memanggil Terdakwa II untuk ke ruangannya. Di ruangannya, Mahendri berkata jika ada pasien yang harus dikeluarkan, dibuang karena pasien tersebut teriak- teriak mengganggu pasien yang lainnya dan tidak ada keluarganya. Setelah Para Terdakwa dan pasien tersebut berada di dalam mobil ambulance, Terdakwa I membawa mobil ambulance meninggalkan RSUD Dr. A Dadi Tjokrodipo Bandar Lampung. Heriansyah memerintahkan untuk dibuang di pasar agar ada yang menemukan dan memberi makan. Namun, melihat kondisi pasien yang lemah dan ada bekas infus, akhirnya Para Terdakwa sepakat untuk membuang pasien tersebut di sebuah gubuk di pinggir Jalan Raden Imba Kesuma, Bandar Lampung. Pada hari Selasa, tanggal 21 Januari 2014, pasien tersebut ditemukan oleh warga dalam kondisi lemah dan tidak bisa bicara, lalu dibawa kembali ke RSUD Dr. A Dadi Tjokrodipo Bandar Lampung untuk mendapatkan perawatan. Namun, pasien kemudian dirujuk ke RSUD Abdul Moeloek. Kondisi pasien saat diterima dalam keadaan gelisah, tidak sadarkan diri, dan lemah. Berdasarkan pemeriksaan dari dr. Yulia Rossi diketahui kulit perut sudah turun, kaki tangan dingin, dan tekanan darah rendah. Pasien Sudarman kemudian dirawat untuk dilakukan observasi, namun enam jam kemudian pasien Sudarman meninggal dunia.

Para Terdakwa dijerat dengan Pasal 197 ayat (1) dan (2) KUHAP dan Pasal 306 ayat (2) KUHP jo. Pasal 55 ayat (1) ke-1 KUHP serta peraturan lain yang bersangkutan. Majelis Hakim dalam mengadili perkara tersebut menjatuhkan pidana penjara kepada Para Terdakwa selama satu tahun dua bulan. Terhadap Mahendri dan Henriansyah, pihak yang menyuruh Para Terdakwa untuk melakukan tindak pidana tersebut, dilakukan splitsing atau pemecahan berkas dalam proses pengadilannya.

Dalam kasus pasien Suparman, RSUD Dr. A Dadi Tjokrodipo Bandar Lampung tidak sepenuhnya menjalankan kewajibannya dalam melaksanakan fungsi sosial rumah sakit. RSUD Dr. A Dadi Tjokrodipo Bandar Lampung menjalankan fungsi sosialnya tidak menjalankan fungsi sosial dalam hal memberikan fasilitas pelayanan pasien tidak mampu/miskin, namun tetap memberikan pelayanan gawat darurat tanpa uang muka yang diketahui berdasarkan keterangan salah satu saksi, yakni Saiful Anwar, yang membawa pasien Suparman ke rumah sakit. Kemudian, berdasarkan keterangan saksi, dr. Melisha Lisman Gaya, pada hari Senin, tanggal 20 Januari sekitar pukul 09.00 ia melakukan pemeriksaan kembali terhadap pasien Suparman dengan didampingi oleh dr. Pratia dan dari pemeriksaan tersebut hasilnya adalah dehidrasi sudah mulai teratasi dan sudah mulai membaik. Menurutnya, kondisi pasien pada hari itu dalam keadaan gaduh gelisah atau tidak tenang secara psikis, belum diperbolehkan pulang tetapi 
diperbolehkan untuk dirujuk ke Rumah Sakit Jiwa Kurungan Nyawa sesuai dengan hasil diskusi dengan dr. Pratia. Karena dinyatakan sudah membaik dan diperbolehkan untuk dirujuk, hal ini menandakan bahwa kondisi gawat darurat pasien sudah teratasi dengan diberikan tindakan medis di RSUD Dr. A Dadi Tjokrodipo Bandar Lampung. Namun, terdapat ketidaksesuaian antara keterangan saksi tersebut dengan pertimbangan hakim.

Dalam pertimbangannya, Majelis hakim menyatakan bahwa pada hari Senin tanggal 20 Januari 2014 sekitar pukul 16.00 WIB kondisi pasien Suparman masih dalam keadaan sakit parah dan lemah tidak berdaya. Meskipun pada faktanya, tidak ada saksi yang menyatakan hal tersebut, maupun bukti-bukti yang menunjukkan bahwa pasien Suparman saat dikeluarkan dalam keadaan sakit parah dan lemah tidak berdaya. Menurut dr. Melisha saat ia memeriksa pada pukul 09.00 nya kondisi pasien Suparman sudah membaik dan diperbolehkan untuk dirujuk. Hal ini juga dikuatkan oleh keterangan saksi dr. Pratia yang mengatakan penanganan penyakit kekurangan asupan makanan sudah mulai teratasi. Oleh karena itu, menurut penulis pertimbangan hakim tersebut tidak berdasar dan RSUD Dr. A Dadi Tjokrodipo Bandar Lampung telah menjalankan fungsi sosialnya dalam hal memberikan pelayanan gawat darurat tanpa uang muka.

Disisi lain, RSUD Dr. A Dadi Tjokrodipo tidak menjalankan fungsi sosial dalam hal memberikan fasilitas pelayanan pasien tidak mampu/miskin. Pasien Suparman yang diduga mengalami gangguan jiwa tersebut tidak memiliki keluarga, sehingga ada indikasi bahwa pasien tidak dapat membayar biaya rumah sakit. Meskipun dalam Pasal 30 UU Rumah Sakit dinyatakan bahwa salah satu hak dari rumah sakit ialah untuk menerima imbalan jasa atas pelayanan kesehatan yang telah diberikan, seharusnya dalam kondisi seperti ini, rumah sakit dapat mengkoordinasikan hal tersebut dengan dinas kesehatan setempat. Para dokter yang memeriksa pasien Suparman juga telah menyarankan agar pasien dapat dirujuk ke rumah sakit jiwa karena adanya dugaan bahwa pasien mengalami gangguan kejiwaan. Akan tetapi, pasien Suparman yang masih membutuhkan perawatan medis dibuang dan ditelantarkan di sebuah gubuk tanpa menghubungi rumah sakit jiwa, dinas kesehatan ataupun dinas sosial setempat. Hal tersebut sangatlah tidak dibenarkan. Seharusnya pihak rumah sakit dapat memberikan pelayanan yang optimal, bukan menyebabkan kondisi pasien semakin kritis dengan dibuang dan ditelantarkan begitu saja sampai akhirnya nyawanya tidak dapat tertolong. Oleh karena itu, RSUD Dr. A Dadi Tjokrodipo Bandar Lampung tidak menjalankan fungsi sosial dalam hal memberikan fasilitas pelayanan pasien tidak mampu/miskin.

2) Kasus Bayi Debora

Berdasarkan press release RS Mitra Keluarga Kalideres tertanggal 7 September 2017, dijelaskan bahwa bayi Tiara Debora Simanjorang berumur 4 bulan, berat badan 3,2 kg diantar kedua orang tuanya ke IGD RS Mitra Keluarga Kalideres pada tanggal 3 September 2017 pukul 03.40 WIB dalam keadaan tidak sadar dan kondisi tubuh tampak membiru (sianosis). Pasien memiliki riwayat lahir premature, riwayat penyakit jantung bawaan (PDA), dan keadaan gizi kurang baik. Dalam pemeriksaan, diketahui nafas berat dan dalam, dahak banyak, saturasi oksigen sangat rendah, nadi 60 kali per menit, suhu badan 39 derajat celcius. Saat bayi Debora dilarikan ke IGD, dokter jaga yang sedang bertugas pada waktu itu, dr. Iren, langsung memberikan tindakan penyelamatan nyawa (life saving) berupa penyedotan lendir, pemasangan selang ke 
lambung dan intubasi (pasang selang nafas), lalu dilakukan bagging (pemompaan oksigen dengan menggunakan tangan melalui selang nafas), infus, obat suntikan dan diberikan pengencer dahak (nebulizer). Kemudian, dilakukan pemeriksaan laboratorium dan radiologi. Kondisi bayi Debora setelah dilakukan intubasi lebih membaik, meskipun masih dalam kondisi kritis.

Selanjutnya, dokter menganjurkan untuk melakukan penanganan di ruang PICU agar dapat memberikan pertolongan maksimal. Hal ini kemudian dibicarakan ke bidang administrasi, di situlah kemudian ada pembicaraan mengenai berapa persen uang muka yang harus dibayarkan dan sebagainya. Seharusnya uang muka yang dibayarkan $80 \%$ dari biaya seharusnya, yaitu sebesar Rp19.800.000,00 (sembilan belas juta delapan ratus ribu rupiah). Namun, orang tua bayi Debora hanya memegang uang sekitar Rp5.000.0000,00 (lima juta rupiah) pada saat itu, sehingga pihak rumah sakit berkata bahwa jumlah tersebut masih kurang dan diberikan kesempatan untuk paling tidak membayar uang muka sebesar 50\% (lima puluh per seratus) dari jumlah seharusnya. Ayah bayi Debora mengatakan bahwa ia memiliki BPJS, namun pihak rumah sakit belum bekerja sama dengan BPJS.

Pukul 06.00 WIB, kondisi bayi Debora terus menurun, kedua orang tuanya terus berusaha mencari rumah sakit lain yang memiliki layanan ruang PICU, hingga pada akhirnya berencana untuk memindahkan ke RS Koja. Setelah berkoordinasi dengan pihak RS Koja, pada pukul 10.00 WIB, perawat memanggil kedua orang tua Debora, mereka mengabarkan kondisi bayi Debora semakin memburuk. Mereka memberikan tindakan CPR karena jantung bayi Debora berhenti. Namun, nyawa Debora sudah tidak bisa diselamatkan. Terhadap kasus bayi Debora tersebut, Dinas Kesehatan DKI Jakarta membentuk tim investigasi untuk melakukan audit medis dan manajemen di RS Mitra Keluarga Kalideres. Dari hasil audit medis, disebutkan bahwa Dokter IGD yang menangani bayi Debora sudah melakukan penanganan medis dengan baik. Namun, terhadap hasil audit manajemen, tim investigasi menyimpulkan bahwa Direktur RS Mitra Keluarga Kalideres kurang memahami peraturan perundang-undangan terkait rumah sakit, yang mana mengatur bahwa pasien gawat darurat tidak boleh dimintai uang muka dan tidak boleh dirujuk sebelum kondisinya stabil. Akibat kesalahannya, PT Ragam Sehat Multifita sebagai pemilik RS Mitra Keluarga Kalideres harus merestrukturisasi manajemen termasuk unsur pimpinan sesuai standar kompetensi paling lama dalam waktu satu bulan setelah surat keputusan keluar. RS Mitra Keluarga Kalideres juga harus lulus akreditasi rumah sakit paling lambat enam bulan setelah surat keputusan keluar dan RS Mitra Keluarga Kalideres wajib memberikan laporan tertulis secara rutin kepada Dinas Kesehatan hingga rumah sakit terakreditasi. ${ }^{30}$

Dalam kasus ini, Rumah Sakit Mitra Keluarga Kalideres telah melaksanakan fungsi sosialnya dalam hal memberikan pelayanan gawat darurat tanpa uang muka. Hal ini dibuktikan dengan kesimpulan tim investigasi terhadap audit medis dan audit manajemen di RS Mitra Keluarga. Kesimpulan dari tim investigasi tersebut dituangkan di dalam Surat Keputusan Kepala Dinas Kesehatan Prov. DKI Jakarta Nomor 1796 Tahun 2017 tentang Pemberian Sanksi Kepada Rumah Sakit Mitra Keluarga Kalideres pada tanggal 25 September 2017, yang didalamnya dikatakan:

\footnotetext{
30Jessi Carina, "Akhir Investigasi Kasus Bayi Debora dan Sanksi untuk RS Mitra Keluarga Kalideres," http://megapolitan.kompas.com/read/2017/09/26/06283361/akhir-investigasi-kasus-bayi-debora-dan-sanksiuntuk-rs-mitra-keluarga, diakses 5 November 2017
} 
a. Berdasarkan hasil audit medis yang dilakukan disimpulkan bahwa dokter IGD RS Mitra Keluarga Kalideres telah melakukan tata laksana kegawatdaruratan sesuai dengan standar profesi dan kompetensi dokter Indonesia.

Berdasarkan hasil wawancara penulis dengan M. Luthfie Hakim, S.H., M.H., Pengacara RS Mitra Keluarga Kalideres, bayi Debora saat itu sudah ditangani dengan baik, namun memang kondisinya belum stabil. Saat datang pun sudah dalam kondisi berat dan setelah dilakukan perhitungan skoring dengan pedeatric logistic organ dysfunction didapatkan skor 30 dengan predicted death rate atau kemungkinan meninggal sebesar 79,6\%. Jadi kondisinya dubia ad malam, meragukan atau cenderung tidak bisa sembuh. Menurut dr. Koesmedi Priharto, Sp.Ot., M.Kes., Kepala Dinas Kesehatan Provinsi DKI Jakarta, berdasarkan keterangan dokter yang memegang langsung dan dokter yang menjadi konsultan PICU bayi Debora, semua sudah dilakukan dengan benar. Masalah yang dibicarakan tentang uang, pasien tidak diberikan pelayanan itu tidak benar karena pelayanan tetap dilaksanakan bahkan dilaksanakan di ruang resusitasi. Ruang resusitasi itu hampir sama dengan PICU, namun bedanya ruang tersebut hanya untuk pertolongan sesaat sedangkan PICU adalah ruang perawatan yang intensif.

Keterangan tersebut selaras dengan hasil wawancara penulis dengan Dr. dr. Supriyantoro, Sp.P., MARS, yang tergabung dalam tim investigasi kasus bayi Debora, bahwa kesimpulan yang diambil oleh tim investigasi adalah pada saat bayi Debora datang, ia dalam kondisi berat dan langsung diberikan pertolongan tanpa memikirkan biaya. Artinya rumah sakit telah menjalankan fungsi sosialnya. Lain halnya jika bayi Debora diantar dalam keadaan gawat darurat, kemudian langsung dimintai biaya, maka rumah sakit dapat dinyatakan salah. Tetapi dalam kasus ini tidak. Bayi Debora tidak dipindahkan ke ruang PICU pun karena pasien sampai detik terakhir kondisinya belum stabil sepenuhnya. Oleh karena itu, selama pasien masih belum dapat dipindahkan (transferable) dan jika diangkut akan semakin parah, artinya belum stabil sehingga dikatakan bahwa dalam sisi penanganan medis menurut kesimpulan tim investigasi dikatakan tidak salah prosedur.

b. Berdasarkan hasil audit manajemen yang dilakukan RS Mitra Keluarga Kalideres Jakarta telah terbukti melanggar ketentuan perundang- undangan.

Berita yang tersebar di media massa membuat orang-orang berfikir karena bayi Debora tidak dimasukkan ke ruang PICU kemudian nyawanya menjadi tidak bisa tertolong/meninggal. Berdasarkan hasil wawancara penulis dengan $M$. Luthfie Hakim, S.H., M.H., ia menanyakan hal tersebut kepada dokter yang menangani bayi Debora, apa yang dibicarakan dokter pada saat itu sehingga orang-orang berfikir seperti demikian, kemudian dokter menjawab bahwa ia hanya mengatakan bayi Debora akan lebih baik jika dibawa ke ruang PICU. Menurut M. Luthfie Hakim, S.H., M.H., kelemahannya ada pada kata-kata dokter tersebut karena terkesan memberi harapan. Padahal kenyataannya jika dipindahkan ke ruang PICU pun belum pasti bayi Debora akan selamat. Akan lebih baik jika bicaranya lebih memberikan gambaran yang tidak terlalu membangun harapan. Hal yang menjadi alasan tidak dipindahkannya bayi Debora ke ruang PICU adalah karena kondisinya belum stabil untuk dapat dipindahkan, dikarenakan nafas bayi Debora masih di bagging, saturasinya masih naik turun, denyut nadinya pun belum stabil bahkan nyaris tidak 
bisa terdeteksi. Akan tetapi, yang tersebar di media adalah karena tidak punya cukup uang maka kemudian bayi Debora terlantar, ada pembiaran dan meninggal.

Lebih lanjut, menurut keterangan Dr. dr. Supriyantoro, Sp.P., MARS, saat penulis wawancarai di Hotel Borobudur Jakarta, berita yang tersebar luas di media massa bahwa orangtua bayi Debora langsung dimintai biaya itu tidak sepenuhnya benar, ayah bayi Debora mengakui pada saat ia dan tim investigasi mendatangi rumahnya untuk meminta keterangan, bahwa anaknya ditangani dengan baik dan kemudian tidak ada pembayaran satu rupiah pun di awal-awal. Bahwa kemudian dimintai biaya itu sebagai antisipasi bahwa jika nanti kondisi bayi Debora stabil maka mungkin dirujuk atau dipindahkan ke ruang PICU. Setelah Ibu dari bayi Debora menyatakan keberatan terhadap biaya ruang PICU mengingat kondisi keuangannya, dokter IGD pada saat itu menawarkan kepada ibu pasien untuk dibantu merujuk ke rumah sakit yang bekerja sama dengan BPJS, demi memandang efisiensi dan efektivitas biaya perawatan pasien. Menurut M. Luthfie Hakim, S.H., M.H., pada kasus rumah sakit yang tidak bekerja sama dengan BPJS, maka pada kasus gawat darurat, ia harus menangani dulu pasiennya sampai kondisinya stabil atau sampai melewati masa daruratnya (life saving). Apabila ia sudah stabil dan sudah dapat dipindahkan, maka harus dipindahkan. Hal ini sebagaimana diatur dalam Pasal 33 Peraturan Presiden Nomor 12 Tahun 2013 tentang Jaminan Kesehatan bahwa peserta yang memerlukan pelayanan gawat darurat dapat langsung memperoleh pelayanan di setiap fasilitas kesehatan dan peserta yang menerima pelayanan kesehatan di fasilitas kesehatan yang bekerjasama dengan BPJS Kesehatan, harus segera dirujuk ke fasilitas kesehatan yang bekerjasama dengan BPJS Kesehatan setelah keadaan gawat daruratnya teratasi dan pasien dalam kondisi dapat dipindahkan.

Berdasarkan keterangan Dr. dr. Supriyantoro, Sp.P., MARS, mencari rumah sakit lain tujuannya jika nanti seandainya harus dirujuk sudah ada rumah sakit yang menerima dalam kondisi tersebut. Menjadi masalah ketika rumah sakit juga meminta keluarga pasien untuk mencari rumah sakit rujukan. Seharusnya apabila dirujuk yang mencari rumah sakit lain adalah rumah sakitnya bukan keluarganya karena rumah sakit yang tahu kondisi pasien. Rumah sakit yang harus memberikan informasi secara medis tentang kondisi pasien, tidak bisa keluarganya supaya rumah sakit yang dituju dipastikan mampu membantu atau tidak dan kemudian sekaligus menyiapkan apabila ada pertolongan khusus yang harus dilakukan. Hal tersebut yang dianggap sebagai kelalaian dari rumah sakit. Dr. Koesmedi Priharto, Sp.Ot., M.Kes., Kepala Dinas Kesehatan Provinsi DKI Jakarta menuturkan, walaupun Rumah Sakit Mitra Keluarga Kalideres juga mencari rumah sakit rujukan melalui telepon, tetapi pihak rumah sakit juga meminta pihak pasien untuk mencari rumah sakit rujukan. Padahal seharusnya hal tersebut dilakukan oleh rumah sakit. ${ }^{31}$ Jadi, berdasarkan audit manajemen, disimpulkan bahwa kurangnya pemahaman direksi tentang peraturan perundang-undangan terkait rumah sakit. Tidak ditemukan regulasi prosedur pemberian informasi kriteria pembiayaan pasien masuk UGD di luar pasien umum dan asuransi. Selain itu, rumah sakit dinilai tidak melakukan diklat untuk direksi dan pimpinan rumah sakit. Selanjutnya, rumah sakit juga belum membuat regulasi tata kelola sesuai undang-undang yang berlaku.

${ }^{31}$ dr. Koesmedi $\quad$ Priharto, $\quad$ Sp.Ot., $\quad$ M.Kes., $\quad$ Konferensi $\quad$ Pers
https://www.youtube.com/watch?v=ZNzsgH2fknU, diunduh 27 Desember 2017. 
Setelah audit medis dan audit manajemen terhadap RS Mitra Keluarga Kalideres dilakukan oleh tim investigasi, dikeluarkan Surat Keputusan Kepala Dinas Kesehatan Prov. DKI Jakarta Nomor 1796 Tahun 2017 tentang Pemberian Sanksi Kepada Rumah Sakit Mitra Keluarga Kalideres pada tanggal 25 September 2017, Dinas Kesehatan DKI Jakarta memutuskan untuk memberikan sanksi sebagai berikut:

a) PT Ragam Sehat Multifita sebagai pemilik Rumah Sakit Mitra Keluarga Kalideres harus merestrukturisasi manajemen termasuk unsur pimpinan sesuai standar kompetensi paling lama dalam waktu satu bulan setelah surat keputusan keluar;

b) Rumah Sakit Mitra Keluarga Kalideres harus melaksanakan dan lulus akreditasi rumah sakit paling lambat enam bulan sejak surat keputusan keluar;

c) Rumah Sakit Mitra Keluarga Kalideres harus bersinergi dengan Dinas Kesehatan DKI Jakarta dengan membuat laporan bulanan tentang capaian perbaikan hingga rumah sakit terakreditasi; dan

d) Rumah Sakit Mitra Keluarga Kalideres harus melakukan peningkatan kapasitas tenaga medis, kesehatan dan nonkesehatan, secara berkesinambungan.

Apabila poin a dan poin b tidak dilakukan, maka Dinas Kesehatan DKI Jakarta akan menghentikan operasional Rumah Sakit Mitra Keluarga Kalideres sesuai ketentuan Pasal 27 huruf c UU Rumah Sakit, yaitu izin rumah sakit dapat dicabut jika terbukti melakukan pelanggaran terhadap peraturan perundang-undangan.

Kesimpulannya adalah tim investigasi tidak menemukan adanya kesalahan atau penundaan tindakan terhadap bayi Debora akibat biaya yang diminta. Tindakan tetap dijalankan untuk menyelamatkan nyawa bayi Debora walaupun sempat ada perkataan bahwa masuk PICU diperlukan biaya. Untuk itu, RS Mitra Keluarga Kalideres telah melaksanakan salah satu fungsi sosial rumah sakit dalam bentuk memberikan pelayanan gawat darurat tanpa uang muka sesuai dengan yang diatur dalam UU Rumah Sakit, Undang-Undang No. 36 Tahun 2009 tentang Kesehatan, KODERSI, Peraturan Menteri Kesehatan RI Nomor 69 Tahun 2014 tentang Kewajiban Rumah Sakit dan Kewajiban Pasien, Peraturan Menteri Kesehatan RI No. 378/Menkes/V/1993, tentang Pelaksanaan Fungsi Sosial Rumah Sakit Swasta, Keputusan Menteri Kesehatan RI No. 129/Menkes/SK/II/2008 tentang Standar Pelayanan Minimal Rumah Sakit dan Keputusan Menteri Kesehatan RI No. 856/Menkes/SK/IX/2009 tentang Standar Instalasi Gawat Darurat Rumah Sakit.

\section{KESIMPULAN}

Berdasarkan uraian pada bagian-bagian sebelumnya, dapat ditarik kesimpulan sebagai berikut:

1. Pengaturan mengenai fungsi sosial rumah sakit di Indonesia terdapat di dalam:

1) Undang-Undang No. 44 Tahun 2009 tentang Rumah Sakit, khususnya Pasal 2 dan penjelasannya, Pasal 29 ayat (1) huruf $f$, Pasal 29 ayat (3);

2) Undang-Undang No. 36 Tahun 2009 tentang Kesehatan, khususnya Pasal 32 ayat (1) dan (2) serta Pasal 190 ayat (1) dan (2);

3) Kode Etik Rumah Sakit Tahun 2015, khususnya Pasal 9;

4) Peraturan Menteri Kesehatan RI Nomor 69 Tahun 2014 tentang Kewajiban Rumah Sakit dan Kewajiban Pasien;

5) Peraturan Menteri Kesehatan RI No. 378/Menkes/V/1993, tentang Pelaksanaan Fungsi Sosial Rumah Sakit Swasta; 
6) Keputusan Menteri Kesehatan RI No. 129/Menkes/SK/II/2008 tentang Standar Pelayanan Minimal Rumah Sakit;

7) Keputusan Menteri Kesehatan RI No. 856/Menkes/SK/IX/2009 tentang Standar Instalasi Gawat Darurat Rumah Sakit.

Bahwa ketujuhnya mengatur agar pasien yang kurang/tidak mampu dapat memenuhi kebutuhan akan pelayanan kesehatan di rumah sakit.

2. Dalam Putusan No. 381/Pid.B/2014/PN.TK, dalam kasus pasien Suparman, RSUD Dr. A Dadi Tjokrodipo Bandar Lampung menjalankan fungsi sosialnya dalam hal memberikan pelayanan gawat darurat tanpa uang muka karena menerima pasien Suparman saat kondisinya gawat darurat dan memberikan perawatan sampai kondisi gawat daruratnya teratasi, tetapi tidak menjalankan fungsi sosial dalam hal memberikan fasilitas pelayanan pasien tidak mampu/miskin karena pasien Suparman yang masih membutuhkan perawatan medis dibuang dan ditelantarkan di sebuah gubuk di pinggir jalan Raden Imba Kusuma, Tanjung Karang Barat, Bandar Lampung, yang menyebabkan kondisinya semakin parah hingga akhirnya meninggal dunia. Sedangkan dalam kasus bayi Debora Rumah Sakit Mitra Keluarga Kalideres dianggap telah melaksanakan fungsi sosialnya dalam hal memberikan pelayanan gawat darurat tanpa uang muka karena saat bayi Debora datang dalam kondisi gawat darurat, Rumah Sakit Mitra Keluarga Kalideres langsung memberikan pelayanan medis atau penyelamatan nyawa terhadap bayi Debora tanpa meminta uang muka.

\section{SARAN}

1. Untuk rumah sakit, sebaiknya memaksimalkan pelaksanaan fungsi sosialnya agar pasien yang kurang/tidak mampu dapat memenuhi kebutuhan akan pelayanan kesehatan.

2. Untuk pemerintah, sebaiknya:

1) Menyelenggarakan dan/atau memastikan tersedianya fasilitas kesehatan yang terjangkau bagi masyarakat;

2) Melakukan sosialisasi berkala berkaitan dengan fungsi sosial rumah sakit kepada rumah sakit-rumah sakit di Indonesia; dan

3) Memaksimalkan pelaksanaan fungsi pengawasan dan fungsi pembinaan khususnya berkaitan dengan hak dan kewajiban dari pasien dan rumah sakit.

\section{DAFTAR PUSTAKA}

dan Sri Mamudji. Penelitian Hukum Normatif Suatu Tinjauan Singkat. Jakarta: Rajawali Pers, 2001.

Andrianto, Wahyu. "Penanaman Modal Asing pada Rumah Sakit, Implikasi pada Fungsi Sosial dan Orientasi Profit.” Skripsi Universitas Indonesia, Depok, 2002.

Carina, Jessi. "Akhir Investigasi Kasus Bayi Debora dan Sanksi untuk RS Mitra Keluarga Kalideres." http://megapolitan.kompas.com/read/akhir-investigasi-kasus-bayidebora-dan-sanksi-untuk-rs-mitra-keluarga. Diakses 5 November 2017.

Fardianto, Fariz. "6 Terdakwa Pembuang Pasien di Bandar Lampung di Vonis 14 Bulan." https://www.merdeka.com/peristiwa/6-terdakwa-pembuang-pasien-di-bandarlampung-divonis-14-bulan.html. Diakses 3 November 2017. 
Guwandi, J. Hospital Law Emerging Doctrines and Jurisprudence. Jakarta: Balai Penerbit Fakultas Kedokteran Universitas Indonesia, 2002.

Kansil, CST. Pengantar Hukum Kesehatan Indonesia. Jakarta: PT Rineka Cipta, 1991.

Kumparan.com. "Bayi Debora Meninggal di IGD RS Mitra Keluarga, Uang Muka Jadi Kendala." https://kumparan.com/salmah-muslimah/bayi-debora-meninggal-di-igd-rsmitra-keluarga-uang-muka-jadi-kendala. Diakses 3 November 2017.

Machmud, H. Syahrul. Penegakan Hukum dan Perlindungan Bagi Dokter yang Diduga Melakukan Medikal Malpraktek. Bandung: CV. Karya Putra Darwati, 2012.

Mamudji, Sri. et al. Metode Penelitian dan Penulisan Hukum. Jakarta: Badan Penerbit Fakultas Hukum Universitas Indonesia, 2005.

Perhimpunan Rumah Sakit Seluruh Indonesia. Kode Etik Rumah Sakit Indonesia. Jakarta: Perhimpunan Rumah Sakit Indonesia, 2007.

Soekanto, Soerjono. Pengantar Penelitian Hukum. Depok: UI Press, 2007.

\section{PERATURAN PERUNDANG-UNDANGAN}

Indonesia. Undang-Undang Kesehatan, UU No. 36 Tahun 2009, LN No. 144 Tahun 2009, TLN No. 5063 .

. Undang-Undang Rumah Sakit, UU No. 44 Tahun 2009, LN No. 153 Tahun $\quad$ 2009, TLN No. 5072.

, Menteri Kesehatan. Peraturan Menteri Kesehatan tentang Pelayanan Kesehatan Swasta dibidang Medik, Nomor PM 920 Tahun 1986.

, Menteri Kesehatan. Peraturan Menteri Kesehatan tentang Pelaksanaan Fungsi Sosial Rumah Sakit Swasta, Nomor PM 78 Tahun 1993.

, Menteri Kesehatan. Peraturan Menteri Kesehatan tentang Pola Tarif Nasional Rumah Sakit, Nomor PM 85 Tahun 2015. 